\title{
Dependability of Financial Investors on Amman Stock Exchange Index
}

\author{
Juma'h M. Abbad ${ }^{1}$ \\ ${ }^{1}$ Financial and Banking Department, Al al-Bayt University, Mafraq, Jordan \\ Correspondence: Juma'h M. Abbad, Financial and Banking Department, Faculty of Finance and Business \\ Administration, Al al-Bayt University, PO. Box 130040, Mafraq 25113, Jordan. Tel: 962-7-7768-8811. E-mail: \\ drabbad@aabu.edu.jo
}

Received: January 26, 2012

Accepted: March 17, 2012

Published: May 1, 2012

doi:10.5539/ijbm.v7n9p141

URL: http://dx.doi.org/10.5539/ijbm.v7n9p141

\begin{abstract}
This study tried to know the dependency of investors on Amman Stock Exchange Index when making their investment decision in the stock exchange, especially when increasing investment opportunities at a rapid rate where the need is urgent for an accurate indicator that can be relied upon to measure the performance of the stock exchange and its effectiveness, the stocks represented for this indicator a lion's share of stock exchange on different sectors, represented by the stock exchange and therefore of the economy. As well as the study attempted to determine the impact of the Arab bank's stocks on the value of the Stock Exchange Index, to reach this goal, a questionnaire was distributed to a group of investors, using the statistical analysis by the adoption of the Wilcoxon test the questionnaire was analyzed. The results showed that ordinary investors do not rely on the index in the short term, while companies and investment portfolios based upon it in their investment decision, as well as there is a direct impact of the Arab bank's stocks on the value of the index. A set of recommendations was put forward by the researcher hoping to help bring the attention of officials and investors to increase the effectiveness of the index.
\end{abstract}

Keywords: dependability, investor, Amman stock exchange, Jordan

\section{Introduction}

Investing in securities is the most interesting topic in modern times, when we observe in practice the volatility in stock prices of stocks and bonds; it comes to mind many questions that are most important to what happens to this volatility? What is the cause? All are questions to be answered, therefore, the great role played by stock markets in the economies of countries, which is of a private financial nature, so the safety of the good performance of these institutions and financial markets is reflected on the safety and good economic performance of the state in general, as well as the degradation and the low efficiency of the financial markets, their impact do not focus on the financial markets (stock exchanges), but extends to other economic sectors as a whole.

The signs of the stock exchanges were emerged to measure the price movements of stocks and bonds on the stock market, therefore these indicators have received a great deal of our attention in this study, we tried to emphasize on Amman Stock Exchange index and the essence of Amman Stock Exchange and study the movements of stock prices in the stock market and the dependence of investors on Amman stock exchange index. The use of market indices help to track the performance of the portfolio and the market situation in general, where the investor is looking on the changes as they happen and in a clear and easy way to use, if Dow Jones fell by (40) points, for example, it means that the average stock prices of the thirty companies constituting the index fell (40) points and therefore this index is an evidence of the general situation of the market.

Thus, the indices serve as an assessment of the state of the market, some of which cover specific industries, others include the economy as a whole, in addition to their role in determining the direction of the market, such indicators have become an investment tools that can predict their future value and determine specific values for the ups and downs of these indices, which translated into monetary values and thus real investment that can reap the profits and losses due to knowing it and subscribing in it, studying Amman Stock Exchange Index gives us the opportunity to learn about this indicator and how to measure it, this research is done to all investors 
regardless of the scientific and practical qualifications, allowing us to know their views on this indicator and the extent of their dependency on it. So this research aims to identify the equity indices, the stock market and focus primarily on Amman Stock Exchange index and its importance for investors and how to display in reality and extent of the investors' adoption.

\section{The Stock Market in Terms of its Conception, Inception and Its Most Important Functions}

\subsection{First: The Definition of Stock Market}

The origin of the word stock attributed to someone from the city of Bruges / Belgium named Van der Burs, where the habits of this person were to meet in his shop with a number of circulations to complete their operations. The stock market is a regulated market in which the dealers were met to buy and sell at certain times and in a particular place. The stock exchange is the backbone of the capital market; it is in its performance like a nervous system, which is reflected through all political indicators, administrative capacity and economic policies.

\subsection{Second: Stock Emergence}

The emergence of stock is originated to the Romans in the fifth century BC, at the beginning of the seventeenth century, the demand for handling stocks had increased, where thousands of investors were heading to Amsterdam to offer the stocks of East India Company at the time, London Stock Exchange had occupied the first financial position in the world rather than Amsterdam, but after the first and second World War, the English empire shrunk back and New York Center appeared after the economic crisis (1929) and the New York Stock Exchange and Wall Street took the first place, where the size of the trading was seven times bigger than the size of trading in London Stock Exchange at the time.

\section{Stocks Index}

We can define the index as a tool used to honestly identify trends and market financial behavior, indications stock exchanges have appeared in order to measure the movements of the market in the short term, indicators represent a group of companies represented to the circulated stocks in the market and their prices movement, reflect the future trends of prices and thus become a tool of speculation with the intention of making a profit.

\subsection{Basic Usage of Indicators for the Stock Exchanges}

(i) Follow up and evaluate the performance of portfolios of financial investments: The index reflects the relationship between returns and market risk for what it includes of securities and reflects the changing value of the indicators of all movements in the prices of circulated stocks on the stock exchange.

(ii) Predicting the movement of stock exchange markets: Technical and fundamental analysis to the changes arising on the indicators measurement of the market prices movement, which enable us to identify these changes and thus to predict the evolution of price movements and taking advantage of them when making investment decisions.

(iii) Regular use of risks factor in the best estimate of the financial investment portfolios: These indicators will assist in the regular calculation of risk beta $(\beta)$ provided that these indicators are well-diversified variety.

(iv) Future predicting of the development of the market: Through determining the link between economic, political, security and other variables with the variables that control the capital market index.

\subsection{Indicators Used in Global Securities Markets}

To measure the movement and trends of market prices, the financial indicators are used to measure the movement and trends of the price in the securities markets. The most important of these indicators; Dow Jones, S \& P 500 index, which was built on a weighted basis. It is assumed in the case of taking the index to rise that the entire market is bound to rise, the daily movement of the stock market can be calculated by dividing the total market values of dealing stocks every day on the total stocks of these companies.

\subsection{Indicators of Global Stock Markets}

\subsubsection{Dow Jones}

It is one of the monthly indicators in the U.S. stock exchanges. Dow Jones indicators is the oldest and most famous indicator was first published in 1897 in Wall Street Newspaper in New York. This indicator is the first calculated average for distinguished stocks prices in the New York Stock Exchange. The index initially stands on 
a sample of (9) stocks for nine industrial companies, increased its size to (12) stocks in 1896 and then to the (20) stocks in 1916. In 1928 the volume of the sample had reached to (30) stocks and since then it has not added any stock to the sample, those stocks represent (30) companies with an average stock of each company, these companies characterized with high market value, the magnitude of size and the number of shareholders. Dow Jones index includes (30) American companies, which are pioneers in the industrial, technological and service sector. Although it is not the best indicator in terms of technical aspect, but it is very popular, it is the most common indicator.

When the stock price rises to reach the summit and then to fall to the bottom, the area located between the two areas is called the resistance area, if the price rose more than the resistance area, this is a sign to buy stocks and if the price fells to the resistance area, it is a sign for the sell of stock, the aim of the resistance area idea is buying when the price rises and sell when the price drops.

\subsubsection{S\&P 500 Index}

It is one of the monthly indicators in the U.S. stock markets, this index uses total market value of the stocks and it is considered a standard record and not an average, it is different from the Dow Jones index that it takes into account the calculated weights, while the Dow Jones neglects weights and calculates using the arithmetic mean.

This indicator reflects the stocks of (500) companies; the value of the index is calculated on the market value basis of the stocks for (500) companies included in the index compared with the market value of the property rights of companies in the previous day, and that the rate of increase in market value from one day to another will reflect the increase in the index, this index consists of four indicators: Indicators of (400) industrial companies' stocks, index of public services companies of (40) stocks, index and transport companies with (20) stocks and the company's financial index of (40) stocks, which dates back for the period 1941-1943.

However, the S\&P index is criticized because of the large influence in changing in high stock prices ignoring other low stock prices due to the small number compared to the total number of stocks of the indicators.

\subsubsection{Value Line 1400 Index}

This indicator was established in 1963 with a sample consisting of (1400) companies, divided on different sectors as follows: (1217) industrial companies, (154) subsidiary companies of the services sector and (29) companies for transport sector, given the value of (100) in the base year (1961) which is weighted on the basis of price and therefore adjusted whenever there was a raise in capital or other financial operations.

\subsubsection{Financial Times Index (London Stock Exchange (FT-SE100))}

This index was established in 1983, it is the most famous index and consisting of (100) securities representing (70\%) of the total capital stock.

It responds to the needs of actors to the index representative of the direction of the British stock exchange, at the same time it can be calculated quickly, stock exchange authorities considered that the number of (100) is the optimum number of equity component of this indicator as they may represent the stock market and it is calculated quickly.

This index was created to cover the shortfall, which the Financial Times index of industrial companies is characterized with, which consists of (30) companies entirely appointed by the industry sector, also it is available for the London Stock Exchange indexes, which published around (704) stocks in the year 1989, it has given to it a value of (1000) points in the base year (30/12/1983).

\subsubsection{France Stock Exchange (CAC40) CAC Index}

It is the most famous and widely used, it consists of (40) securities of the most important companies in the Paris Stock Exchange; it covered (40) institutions in base year (1991). It could be argued that supervisors hope of providing accurate information as possible and as soon as to the French Stock Exchange to meet the needs of clients. In view of the sample which is the index, we find that the companies are divided into (8) official sectors:

1- Base Products.

2- Construction Sector.

3- Equipment.

4- Durable Consumer Goods.

5- Endurable Consumer Goods.

6- Foodstuffs. 
7- Services.

8- Financial Institutions.

\subsubsection{Japanese Indexes}

There are indexes in Japanese stock markets especially Tokyo and Osaka stock exchanges, where each tries to reflect the status of the stock markets and its trends. Nikkei index, which was established in 1950, consists of (225) Japanese companies. Despite of this large Japanese institution's fame but the method of calculation has made many observers doubt the credibility of the representation of the direction of stock prices in Japan, as it calculates the collection prices of (225) companies and divides the total on their number, which is simply the arithmetic mean of the sample of its components.

\subsubsection{German Indexes}

There are many German indexes, the most famous are (Fas and Dax. Fas index consists of shares where its value reached in 1990 to (761.48) points, while Dax index consists of (300) shares representing (70\%) of the capital stock which is similar to France's CAC 40 index.

\section{Economic Indicators}

These indicators are indicators that the investor should use to identify future market trends; the economic activity in general is used as an indicator of market rights, so stock market should be always characterized by force.

\section{Amman Stock Exchange (Amman Stock Exchange, 2003)}

Amman Stock Exchange gained a great importance compared with other economic sectors in Jordan, it was considered the only party authorized to perform the work as a disciplinary market for trading securities in the Kingdom and has a legal personality with administrative and financial autonomy and has the right to do all legal acts, including performing contracts, owning movable and immovable property and disposing it. Stock exchange is a non-profit institution and does not subject to the Companies Act and may not do businesses or get a particular benefit in any project or have any securities and is therefore subject to the supervision and control of the Jordan Securities Commission.

5.1 Amman Stock Exchange Achievements in 2008 (Amman Stock Exchange, 2008)

\subsubsection{First: Legislative Developments}

The stock market during the year performed the following:

- Reviewed the Listing Securities Directives and amended it in line with the new version of the electronic trading system (NSC V900) in line with the plan of online trading which is intended to apply, these Directives have been submitted to the Securities Commission for approval.

- Reviewed the manual of the electronic trading system and amended it in line with the new version of the electronic trading system (NSC V900), also in line with the plan of trading via the internet.

- Ratification of the draft online trading directives by the Board of Directors of Amman Stock Exchange, these directives shall enter into effect after the approval from the Securities Commission.

- Participated in the preparation of the corporate governance for companies listed in the Stock Exchange guidance, which was ratified by the Securities Commission and implemented in 2008.

\subsubsection{Second: Technical Developments}

- Online Trading.

- The new version of the electronic trading system.

- Updated the environmental infrastructure of the main network's stock.

- An additional Fiber Optics Line exchange between the site of the stock market and Housing Bank Complex.

- Updated the alternative site of the Stock Exchange.

- Started updating electronic internal and external Amman Stock Exchange portals "Internet and internet Portals". 
- Transferred communication circuits based on copper lines in the Housing Bank Complex to fiber-optic lines.

- Raised the speed of internet main line in Amman Stock Exchange.

- Connected all electronic devices that have two power supplies with different energy sources provider.

- Created a new simulation room at Petra University.

- Installation of management and remote control program with the mediators.

- Applied a special version of monitoring the market program on mobile devices and smart devices.

- Apped the new version of the Management Information System MIS.

- Insider trading.

- A new regulatory system concerned with clients' trading.

- Development of the professional register of the exchange members.

5.1.3 Third: Publication of the free float standard record through the electronic trading system of the Stock Exchange

5.1.4 Fourth: Launching (Dow Jones ASE - 100) index with the collaboration between Dow Jones and Amman Stock Exchange

5.1.5 Fifth: Disclosure and dissemination of information

\subsubsection{Sixth: Awareness and information}

5.1.7 Seventh: Spreading the beta values of listed companies and studying the choice of capital asset pricing model for companies listed in Amman Stock Exchange

5.1.8 Eighth: Dissemination of price rate to the operating cash flow

5.1.9 Ninth: Local, Arab and international cooperation

\subsubsection{Tenth: Companies listed in Amman Stock Exchange}

\subsubsection{Eleventh: Exchange membership}

\subsection{Indices of Stock Prices in Amman Stock Exchange}

The indices are considered the most important indicators in the financial markets, which indicate the levels of stock prices and determine the general direction of prices; these indices are used to measure changes in stock prices during a certain period compared with the other.

In 1980 Amman Financial Market began to calculate an improbable record of stock prices, selecting a sample of (38) companies from all sectors to calculate the general record, the prices of the opening of trading have been set in the first of January 1980 as a basis period, so that the value of the record is (100) points, the basic value changed to (1000) points from the beginning of 2004. Note that, in addition to the general record, indices for all sectors were calculated as follows: banking sector, financial companies, insurance, services and industry.

After extensive statistical studies, Amman Financial Market began in early 1992 to calculate a new record reference in market value, 31 December 1991 was set as a basis period (record=100 points), it was changed to (1000) since the beginning of 2004. This figure is based on the selected sample of (50) companies that represent the market; it was increased to (60) companies in 1994 and to (70) companies in 2001, and (100) companies in 2007. To select this sample, it has adopted five standards that reflect the size of the companies and the extent of their liquidity. These standards represent: market value of the company, the number of trading days, the turnover ratio, trading volume and number of circulated stocks, also the represented sectoral is taken into account when selecting the sample.

As a result of global developments in the fields of calculating the indices to increase the capacity of these figures opposite of the market performance, the Stock Exchange has developed a new record which is based on free stock (available for trading), so that it gives a better representation for the movements of stock prices in the market and reduces the impact of companies with high market value so it can reduce its weight, where this figure was calculated by weighting the market value of available free stocks for trading (Free Float) in companies and not with the total number of stocks listed for each company. This approach is supported by a large number of international institutions that calculate indices for most of the world and considered as one of the biggest 
international companies in supplying indices services, such as (S\&P), the (FTSE Group), Dow Jones Indexes and STOXX.

The standards of Dow Jones Company have been applied in selecting the companies' sample which this figure is calculated on their basis. The range index to all domestic companies are listed in Amman Stock Exchange, while the companies that collectively represent less than $1 \%$ of the total market value of the stock market and companies that do not increase the percentage of their circulated days to $33.33 \%$ of total trading days in each quarter were excluded. The index consists of (100) big companies that met the requirements in terms of market value in the new index. The index weight is identified with the market value of free stocks, while weights of the individual stocks are determined by $10 \%$ as a maximum in order to prevent the dominance of individual stocks on the index. Also it was selected the number (1000) points as a basis value for the record as in the end of the year 1999. This number is characterized that it better reflects the movements of stock prices in the market, as well as it reduces the impact of companies with large market value, in addition, it gives a greater opportunity for small and medium-sized companies to affect its movements.

Indices are calculated in Amman Stock Exchange according to the last available closing prices of companies that are within the sample, these figures are published daily. To enable the record to reverse the true image of companies' stock prices changes listed on the Stock Exchange. The sample is reviewed periodically every (3) months through the study of the companies' dynamic listed on the stock exchange, so the dynamic companies were added to the sample and the inactive companies withdrawn, it can make some emergency adjustments, in case of stopping the companies from trading for a long time, or delete the inclusion of these companies. Necessary adjustments are made on the record so as to exclude the impact of any changes caused by factors other than the change in the movement of stock prices to reflect the indices changes in stock prices only.

\subsection{Amman Stock Exchange Indicators: Taking into Consideration the Stocks Included in its Calculation}

- Number of trading days, it must be large.

- Market value (market price $\times$ issued stocks' number).

- Stocks rotation ratio must be high.

- Dealings value should be significant.

- Number of stocks circulation must be significant.

In addition, it must consider that the index represents the economic sectors consisting the market.

\subsection{Indicators' Types in Accordance to the Stocks' Weights which Constitute the Index}

- Index with equal weights, it is used in Amman Stock Exchange; it is called (Un-weighted Index).

- Weighted index with the stock prices (Price-Weighted Index) this indicator is used in Amman Stock Exchange, (NIKI) and (DJTA); it is called a weighted index.

- Weighted index with market value of stocks, it is the index used in (NASDAQ) and (S\&P); it is called a weighted index.

Un-Weighted index in general is an index that gives an equal weight and its constituent stock has equal weights.

The weighted index, it is the index which the constituent stocks of weights are unequal and differ in their stocks' number or their market value. For Amman Stock Exchange, the weighted index gives a large weight to the market value of the company, it is weighted with the stocks of the Arab Bank which has a market value of (320) dinars which became after the stock split (by 1 to 10) 42 dinars (Amman Stock Exchange, 2005).

\section{The Standard Record of Un-Weighted Stock Prices}

The Un-Weighted record gives an equal weights for all companies of the sample, regardless of their market value or stock price, it gives the importance in this figure to the relative change in the stocks prices, this number is used in the evaluation of investment portfolios that distributed their investments in terms of the value of equally among all companies. Since 1980 it has started to calculate this figure in accordance to a sample of (38) companies to overall record, as well as calculating the indices of all sectors of the banking sector, financial companies, insurance, services sector and industry on a daily basis. Prices of opening were set in the first of January in 1980 as a basis period, the record was given a standard value (100) points, and it was changed from the beginning of 2004 to (1000) points. In 1992, modifications were made to this record to become more flexible in terms of modifications that can be done to exclude the impact of changes resulting from factors other than the change in the movement of stock prices and also changed the basis period to be December 31, 1991 in case that a 
company from the sample record companies had distributed bonus shares or split nominal value of shares or reduced their capital, which lead to an increase or decrease in the market value of the share price. It adjusts the base rate for the company, so as not to affect this decrease (due to fragmentation or bonus shares) or high (in the case of capital reduction) on the movements of the record, without making any adjustments in the case of a company to increase its capital by offering shares for subscription in the case of addition or withdrawal of a company to / from the sample, the amendment shall be by (calculated adjustment coefficient).

\section{The Weighted Record of Stock Prices}

One of the advantages of the record for stock prices weighted by market value is its adoption of weighting method with the market value of the sample's companies, so that it gives each company a weight as much as its market value be from the market value of the sample as a whole, it was set on 31 December, 1991 as a basis period. The market value of the sample's companies has formed a rate of $(90 \%)$ of the market value as a whole in January 21, 1991 as a basis period.

\section{Previous Studies}

- Le Sourd's (2011) study conducts a performance measurement of SRI funds and assesses the impact of changing the reference from a standard SRI index to an efficient SRI index. The analysis of fund performance shows that an efficient SRI index raises the bar for actively managed SRI funds. While about $60 \%$ of funds have a positive information ratio when compared to the cap-weighted EuroStoxx Sustainability Index, only about 25\% of funds do so with respect to the Efficient SRI Index. It is also interesting to note that the median information ratio across funds is slightly positive $(0.05)$ when using the standard SRI index, but it is clearly negative $(-0.22)$ when using the Efficient SRI index.

- Goltz \& Sahoo's (2011) study provides a detailed comparison of the performance of efficient indices and that of the respective cap-weighted indices to account for the sources of this outperformance. The efficient index is built on the concept of finding a proxy for the tangency portfolio by maximizing the Sharpe ratio, and better diversification is a major contributor to the performance of efficient indexation. Efficient indices are at their best when market conditions reward optimal diversification strategies, that is, when cap-weighted indices tend to be most heavily concentrated and when correlations are stable. In addition, the researchers look at the way sector performance contributes to the overall performance of both efficient and cap-weighted indices. Unlike that of the cap-weighted index, the performance of efficient indices is driven more by better diversification across stocks than by shifts in sector weights. Finally, an analysis of the equity risk factor exposures for both efficient and cap-weighted indices confirms that - though exposures of efficient indices are obviously different from those of cap-weighted indices - the performance of efficient indices cannot be explained entirely by simple factor tilts. On the whole, the study's results suggest that improved diversification is a key source of the outperformance of efficient indexing.

- Amenc's etal. (2011) paper analyzes a set of equity indices whose aim is to improve on capitalization weighting and thus to provide "improved beta". Four main weighting schemes are analyzed: efficient indices, fundamental indices, minimum-volatility indices and equal-weighted indices. Empirical results for US and Developed World data on these indices show that the average returns of all four alternative index construction methods are superior to those of cap-weighted equity indices in both universes and that, by several measures of risk-adjusted performance, they are likewise superior. The researchers also analyzed factor exposures of alternative weighting schemes. Only the fundamental index has a value exposure that is substantially greater than that of the equal-weighted index. Other non-cap-weighted indices such as efficient indexation and minimum volatility have value exposures that are comparable to that of equal weighting. Since the indices studied here are made up of large-cap stocks, none of these indices shows any economically meaningful bias towards small caps. Interestingly, the minimum-volatility index, similar to the cap-weighted indices, shows a negative small-cap exposure since it favors the largest stocks.

- A business-finance.org (2011) study begins with a review of the Future Optimal Hedge Ratio theory, classifying the theory into five categories-the minimum variance model, the mean-variance model, the expected utility maximization model the mean extended-Gini coefficient model as well as the semi variance model- and elaborate on parameter estimations of each model and further research on the relationships between models. Then the researcher adapts the minimum variance model to the domestic environment and come up with a Future Optimal Hedge Ratio model. Utilizing CSI 300 Index (I) makes an empirical study on the effectiveness of the future hedge on four investment portfolios. The conclusions are that: first, the model solves the data shortage problem effectively. And there exists a systematic bias in the future-spot data substitution and coefficient. So revisions are needed. The research also finds the original hedge ratio computed from spot data for performance 
evaluation is right. Second, Empirical studies have shown that the higher the coefficient between the portfolio and CSI 300 Index, the better the future hedge works, which is consistent with the theoretical model.

- Fayoumi's (2003) study was on the choice of the efficiency of Amman Stock Exchange by focusing on the availability of appropriate information to investors easily and fairly, without costs and how quickly it is reflected in stock prices through the use of market index in the period between 1993-2000, the results of the study showed that the legislative and technical developments witnessed by Amman Stock Exchange since 1997 had a positive impact, making the market more efficient than the previous period, which reinforces the confidence of investors in the stock market.

- Badri and Khoury's (1997) study aimed at knowing the relationship between price movements of exchanged stocks on Amman Stock Exchange and the change in macroeconomic factors using the standard models.

The two researchers studied the following factors:

(i) The standard record of industrial production quantity.

(ii) Standard prices indices.

(iii) General index of stock prices.

The two researchers found that the standard record of the amount of industrial production is taken as an indicator of the level of economic activity, although it represents only one sector of the economy and that the overall economic activity index is important in determining the movements of stock prices, because taking investment decisions in the fixed assets based on net present value of expected cash flows investment.

- Salama's (1997) study stressed on the relationship between the general level change of prices and change stock prices in Jordan; where this study aimed at searching for the nature of this relationship, where the record of living costs index have been taken as a measure of the overall level of prices and the record of stock prices as an indicator that reflects the overall level of prices changes of circulated stocks. The results showed that there was no relationship between the overall level change of prices and stock prices change, since stock prices change independently from changes that occur for the overall level of prices and are not fixed. The interpretation of these results are due to the possibility of the existence of inertia in the expression of records for measuring the level of both the overall level of prices and the overall level of stock prices that reflect real changes that occur to these two variables locally.

- Al-Khatib and Al-Shara's (1994) study relied on measuring the relationship between Amman Stock Exchange indicators and economic variables such as rate of growth of national production, inflation, interest rates on deposits, exchange rates, the standard record of industrial production and money supply. The study confirmed that the return on the stock and the stock price is affected by these variables. The study summarized that Amman Stock Exchange is not a true indication of the nature of the economic situation in Jordan.

- Goetzmann's (1999) study used individual accounts in the S \& P 500 index, the mutual funds index, two years ago, looked into exchanging and investment behavior of more than (91) thousand investors who negatively chose the low cost managed by savings mechanism, this allows us to highlight the heterogeneity of investors in terms of patterns of their investment, in particular the positive responses to traders, as well as the different, which their activities are unconditional of the movements of the stock market today. He found that most repeat traders were different in terms that there were rare traders who were not to be more powerful than the investors, he also found that the behavior of investors, associated with changes in the Stand \& Poor's 500 index and he traced their movement with the passage of time. The researcher conclude that we have to build factors of behavior based on the momentum flows, showing that their performance is well, which reflects the dispersion of beliefs among investors and helps at the expense of asset pricing, which is better than the parameters of the dispersion of beliefs.

- Elton, Gruber \& Busse's (2002) study focused on that the financial theory is often based on the belief of rational investors' acts for price-fixing that leads to the removal of the financial instruments control. Recently a series of articles asking about the behavior of rational investor was published, the index of Stand \& Poor's reflects the stocks of 500 companies, which represents one of the most active mechanisms to examine whether investors make rational decisions that are consistent with the normal form of the financial economy, index Stand \& Poor varies more than $2 \%$ per year in fees, because it is responsible for the returns that are offered to investors. In this paper, it is shown that the relative returns that the index Stand Land Port offers, is easily predictable and shows us other important aspects such as performance, risk and tax efficiency, these can be predicted easily, in spite of the ability to predict and the relationship between the new cash flows and performance, it is much weaker than what the researchers expected on the basis of rational behavior, as well as they see that the choice of 
funds is based on an increase or decrease in past expenditures and revenues that lead to the portfolio and portfolio performance of a selected index funds by investors.

- Yao, Luo \& Morgan's (2010) study shows the relationship between the index of Shanghai Stock Exchange (Small Business Projects) and the composite index of ten Chinese banks to test whether they have played a role in leading the Chinese stock market using daily prices from June 1, 2006 to November 15, 2007. Granger has applied the (The Causal Relationship Test) and found that the causal relationship is unidirectional while the tendency among most of the banking stocks prices and the two-way market index have been identified as the only relationship among the five of the ten banks. This research has created line with previous studies that the stock market in China is an integrated region and seriously affects the psychological factors to the investors.

- Murat \& Renato's (2004) study shows the impact of foreign investors in Istanbul Stock Exchange, as well as their behavior when dealing in the Turkish stock market using the (Var) model with net flow of foreign portfolio returns and the dollar in Istanbul Stock Exchange that show that there is a monthly relationship between these variables. Thus, when foreign investors entering the Turkish market, the Istanbul stock index increases with time, or vice versa, this suggests that foreign investors have adopted a contradictory strategies when trading in the Turkish market, this behavior is not consistent with the preceding experimental studies and there was no positive feedback for trading, there is also no impact of price pressure to foreign investors, so they cannot blame the instability of the Turkish market and foreign investment seems to be more useful to the Turkish market.

\section{Study Hypothesis}

H1: There is a statistically significant relation between Amman Stock Exchange index and the extent of adoption of the investors on it

$\mathrm{H} 2$ : There is a statistically significant relationship between the Arab Bank share and the value of Amman Stock Exchange index

\section{Study Methodology}

\subsection{Study Population and Sample}

The study population consisted of all investors in the Amman Stock Exchange. (50) questionnaires were distributed randomly to investors in the Amman Stock Exchange. (45) have been used, (5) questionnaires were unusable

\section{Discussing the Results of the Statistical Treatment and Testing Hypotheses}

To achieve the objectives of this study, the descriptive statistical methods were used in general to get readings on the characteristics and features of the structure or composition of the population of the study and distributing it, where the frequency distribution, percentages and averages were used. To examine these hypotheses, a Wilcoxon test was used, where this test works to examine whether the arithmetic mean of the values is greater than (3) or less or equal to (3), if the arithmetic mean is less than or equal to (3), this is an acceptance of the null hypothesis $\mathrm{H}_{0}$, but if it was greater than (3), this represents the acceptance of the alternative hypothesis $\mathrm{H}_{1}$ or in a manner more suitable for the process of acceptance or rejection, is what is known as the P-value, if it was less than 5\%, the decision towards to the rejection of the null hypothesis $\mathrm{H}_{0}$ and accept the alternative hypothesis $\mathrm{H}_{1}$. As for the investment decision taken by the respondents, it ranged between (taken by myself), where the rate stood at $57.8 \%$ and between brokers where the rate was $42.2 \%$, which are close somewhat. We also note that most respondents are experienced as the percentage of more than 5 years of experience were accounted for $51.1 \%$ which is almost half of the sample, while the percentage of the experienced that ranged from (1-5) years was $35.6 \%$.

Table 1. Gender

\begin{tabular}{lcc}
\hline Gender & Frequency & Percentage \\
\hline Male & 36 & 0.8 \\
Female & 9 & 0.2 \\
Total & $\mathbf{4 5}$ & $\mathbf{1 0 0 \%}$ \\
\hline
\end{tabular}

Table 2. Age

\begin{tabular}{lcc}
\hline Age & Frequency & Percentage \\
\hline Less than 25 years & 2 & 4.4 \\
26- 30 years & 20 & 44.4 \\
31- 40 years & 14 & 31.1 \\
More than 40 years & 9 & 20.0 \\
Total & $\mathbf{4 5}$ & $\mathbf{1 0 0 \%}$ \\
\hline
\end{tabular}


Table 3. Education level

\begin{tabular}{lcc}
\hline Education level & Frequency & Percentage \\
\hline Diploma & 9 & 20.0 \\
Bachelor & 26 & 57.8 \\
Master & 10 & 22.2 \\
Ph.d & - & - \\
Total & $\mathbf{4 5}$ & $\mathbf{1 0 0 \%}$ \\
\hline
\end{tabular}

Table 4. Nature of work

\begin{tabular}{lcc}
\hline Nature of work & Frequency & Percentage \\
Financial intermediate & 24 & 53.3 \\
Financial investor & 4 & 8.9 \\
Financial analyst & 6 & 13.3 \\
Several financial business & 11 & 24.4 \\
\hline Total & $\mathbf{4 5}$ & $\mathbf{1 0 0 \%}$ \\
\hline
\end{tabular}

Table 5. Investment decision

\begin{tabular}{lcc}
\hline Investment decision & Frequency & Percentage \\
\hline Brokers & 19 & 42.2 \\
Myself & 26 & 57.8 \\
Total & $\mathbf{4 5}$ & $\mathbf{1 0 0 \%}$ \\
\hline
\end{tabular}

Table 6. Experience

\begin{tabular}{lcc}
\hline Experience & Frequency & Percentage \\
\hline Less than one year & 9 & 13.3 \\
$1-5$ years & 16 & 35.6 \\
More than 5 years & 23 & 51.1 \\
Total & $\mathbf{4 5}$ & $\mathbf{1 0 0 \%}$ \\
\hline
\end{tabular}

- Analyzing the first hypothesis that stipulated: There is a statistically significant relationship between the index of Amman Stock Exchange and the extent of the investors' adoption on it.

Table 7. Mean and standard deviation

\begin{tabular}{|c|c|c|c|c|c|c|c|c|}
\hline Item & $\begin{array}{c}\text { Strongly } \\
\text { agree }\end{array}$ & agree & Neutral & Disagree & $\begin{array}{l}\text { Strongly } \\
\text { disagree }\end{array}$ & mean & S.D & P-value \\
\hline $\begin{array}{l}\text { Amman Stock Exchange index contains } \\
\text { the status of diversification. }\end{array}$ & 15.6 & 66.7 & 4.4 & 13.3 & - & 3.84 & 0.852 & 0.000 \\
\hline $\begin{array}{l}\text { Amman Stock Exchange index includes } \\
\text { all economic sectors. }\end{array}$ & 26.7 & 60.0 & 4.4 & 8.9 & - & 4.04 & 0.824 & 0.000 \\
\hline $\begin{array}{l}\text { The investment decision is based on the } \\
\text { trends of the index. }\end{array}$ & 2.2 & 57.8 & 17.8 & 22.2 & - & 3.40 & 0.863 & 0.002 \\
\hline $\begin{array}{l}\text { Amman Stock Exchange index is good } \\
\text { and express the performance of the } \\
\text { market. }\end{array}$ & 6.7 & 55.6 & 17.8 & 17.8 & 2.2 & 3.47 & 0.944 & 0.000 \\
\hline $\begin{array}{l}\text { The presence of an index of the scope } \\
\text { of Arab stock exchanges is better for } \\
\text { the local stock prices. }\end{array}$ & 6.7 & 28.9 & 44.4 & 15.6 & 4.4 & 3.18 & 0.936 & 0.000 \\
\hline $\begin{array}{l}\text { The index does not affected by political } \\
\text { and economic events in the region. }\end{array}$ & 8.9 & 17.8 & 6.7 & 24.4 & 42.2 & 2.27 & 1.405 & 0.000 \\
\hline $\begin{array}{l}\text { The number of days of internal stock } \\
\text { trading in the calculation of Amman } \\
\text { Stock Exchange index must be great. }\end{array}$ & 11.1 & 42.2 & 15.6 & 28.9 & 2.2 & 3.13 & 1.083 & 0.030 \\
\hline $\begin{array}{l}\text { The local investment portfolios of } \\
\text { companies or funds based on the index } \\
\text { to predict the movement of stock in the } \\
\text { future. }\end{array}$ & 4.4 & 53.3 & 24.4 & 15.6 & 2.2 & 3.42 & 0.892 & 0.000 \\
\hline $\begin{array}{l}\text { Amman Stock Exchange index reflects } \\
\text { the dividend of shares. }\end{array}$ & 2.2 & 44.4 & 13.3 & 17.8 & 22.2 & 2.87 & 1.272 & 0.060 \\
\hline $\begin{array}{l}\text { The foreign investment portfolios } \\
\text { depend little on Amman Stock } \\
\text { Exchange index for the purposes of the } \\
\text { investment decision in Jordan. }\end{array}$ & 4.4 & 28.9 & 11.4 & 22.2 & 33.3 & 2.49 & 1.342 & 0.071 \\
\hline $\begin{array}{l}\text { The companies consisting of the index } \\
\text { should have large trading volumes so as }\end{array}$ & 15.6 & 51.1 & 4.4 & 6.7 & 22.2 & 3.31 & 1.427 & 0.000 \\
\hline
\end{tabular}




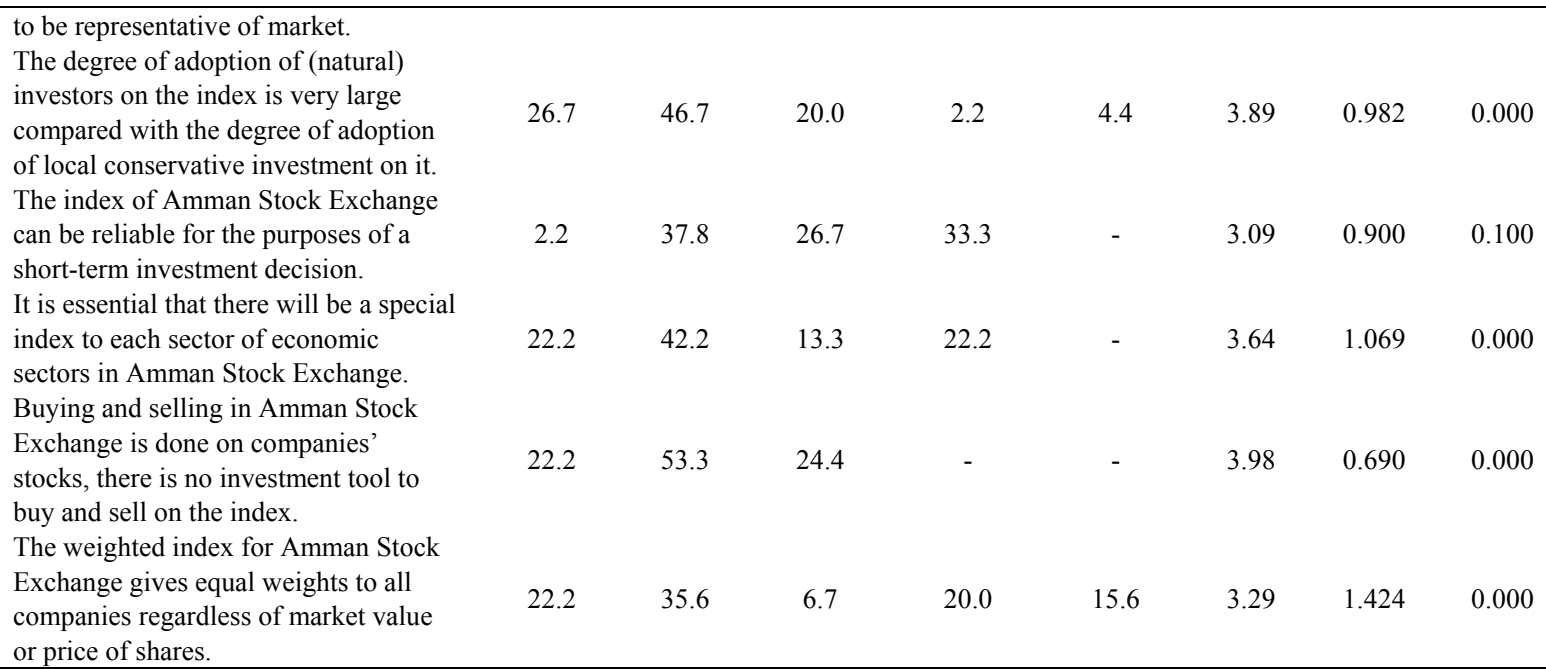

The previous table indicates that most of the paragraphs were answered with "agree" and "strongly agree", where the values (P-value) for all paragraphs were less than 5\%, while the paragraph (Amman Stock Exchange index contains the status of diversification) has received the highest degree of "agreed" with a percentage of $66.7 \%$ and a mean of (3.86), followed by the paragraph (Amman Stock Exchange index includes all economic sectors), where the approval percentage reached $60 \%$ and a mean of $4.04 \%$. The paragraph of (The investment decision is based on the trends of the index) has an approval of 57.8\%, as well as the paragraph (Amman Stock Exchange Index is good and express the performance of the market) has an approval of 55.6\%.

We also note that the paragraph (The index of Amman Stock Exchange can be reliable for the purposes of a short-term investment decision) amounted to P-value has greater than $5 \%$ as it was $(0.100)$, this is due to that about $33.3 \%$ answered "disagree" on this paragraph, as it is known that the price indicators are important and useful for the short term and not for the long term, as with long-term investors do not pay much attention to the index to give for instantaneous and immediate results, while the investor who wants a short term invest or banks, he who will pay attention to the index. The paragraph (The foreign investment portfolios depend little on Amman Stock Exchange index for the purposes of the investment decision in Jordan) has a degree of "strongly disagree" of 33.3\%, and also (Amman Stock Exchange index reflects the dividend of the shares) has an average of (2.49).

- Analyzing the second hypothesis that states: There is a statistically significant relationship between the price of Arab Bank and the value of Amman Stock Exchange index.

Table 8. Mean and standard deviation of second hypothesis

\begin{tabular}{|c|c|c|c|c|c|c|c|c|}
\hline Item & $\begin{array}{c}\text { Strongly } \\
\text { agree }\end{array}$ & agree & Neutral & Disagree & $\begin{array}{l}\text { Strongly } \\
\text { disagree }\end{array}$ & mean & S.D & P-value \\
\hline $\begin{array}{l}\text { The low or high record (index) } \\
\text { for Amman Stock Exchange is } \\
\text { not affected by the movement of } \\
\text { Arab Bank stock. }\end{array}$ & 8.9 & 8.9 & 15.6 & 40.0 & 26.7 & 2.33 & 1.225 & 0.100 \\
\hline $\begin{array}{l}\text { It is believed that the } \\
\text { relationship between the Arab } \\
\text { Bank stock and the value of the } \\
\text { index in Amman Stock } \\
\text { Exchange is a direct correlation. }\end{array}$ & 53.3 & 11.1 & 13.3 & - & 22.2 & 3.73 & 1.629 & 0.004 \\
\hline $\begin{array}{l}\text { It is better to exclude the Arab } \\
\text { Bank stock from the index. }\end{array}$ & 24.4 & 40.0 & 26.7 & 8.9 & - & 3.80 & 0.919 & 0.000 \\
\hline
\end{tabular}

We note from the above table that the low or high index of Amman Stock Exchange is affected by the movement of Arab Bank, where the percentage of "disagree" was $40 \%$ and the arithmetic mean for it was (2.33) which is less than (3) while the value of P-value was (0.100) and that there is a direct correlation between the Arab Bank stock and between the value of Amman Stock Exchange index, where approval percentage to this paragraph was $53.3 \%$ which is almost half and the arithmetic mean was (3.73) as the value of the P-value $=0.004$, finally there are those who prefer to exclude Arab Bank stocks from the index, where the highest percentage of approval reached $40.0 \%$ and (24.4) strongly agree, and the mean was (3.80) and that P-value $=0.000$ which is less than $5 \%$. 


\section{Testing Hypotheses}

The following table shows a summary of the hypotheses, the value of the arithmetic mean value and the P-value:

Table 9. Testing hypothesis

\begin{tabular}{lccccc}
\hline \multicolumn{1}{c}{ Hypothesis } & mean & S.D & T & Df & P-value \\
\hline $\begin{array}{l}\text { There is a statistically significant relation between Amman Stock } \\
\text { Exchange index and the extent of adoption of the investors on it }\end{array}$ & 3.3431 & 0.41493 & 21.714 & 44 & 0.001 \\
$\begin{array}{l}\text { There is a statistically significant relationship between the Arab Bank } \\
\text { share and the value of Amman Stock Exchange index }\end{array}$ & 3.2889 & 0.79328 & 10.899 & 44 & 0.021
\end{tabular}

We note from the previous table that it has proven the first hypothesis, which states (There is a statistically significant relation between Amman Stock Exchange index and the extent of adoption of the investors on it) the value of P-value $=0.001$ which is less than $5 \%$ with arithmetic mean of (3.34131), this means that there is a statistically significant relationship between Amman Stock Exchange index and the extent of adoption by the investors on it, therefore the first hypothesis was proven. As for the second hypothesis, which states (There is a statistically significant relationship between the Arab Bank share and the value of Amman Stock Exchange index), where the value of $\mathrm{P}$-value $=0.021$ which is less than $5 \%$ with arithmetic mean of (3.2889), this indicates that there is a statistically significant relationship between the Arab Bank share and the value of Amman Stock Exchange index, this proves the overall hypothesis.

Also we can come with a set of results through questionnaires that were distributed, or through personal interviews with a group of practiced or ordinary investors. The researcher found that the purchase and sale in Amman Stock Exchange on companies' stocks and there is no investment tool for buying and selling on the index, and therefore many natural investors are not concerned with the index significantly compared with the portfolios of funds and investment companies which have adopted the index as an indicator of future speculations for stocks' movement.

\section{Recommendations}

It is worth mentioning at the end of this research through field and scientific search a set of recommendations, which enable investors engaged in the preparation of the index to adopt it or for the researchers for further research, which are:

- Performing separate indicators for banking, insurance, services and industry sectors.

- We need an accurate indicator that gives early signals for the movement of the stock and thus the movement of the market.

- Increase the awareness of the investors in the stock market with the importance of the indicators and the importance of guidance when deciding to invest in securities, and the main objective of the use of stock indicators in performing market assessment and its performance to allow understanding the general trend of the market and thus can be used as an effective tool to predict the economic situation.

- The need to benefit from the technological development in the field of dissemination of information both in terms of stock market or economic changes and their impact on the index, perhaps the use of the internet for this purpose is a step in the right direction.

\section{References}

Abdul Ghaffar, Hanafi. (2007). Fundamentals of Finance. Egypt: Addar Aljami'ah for Publication.

Al-Bayan Newspaper. (2000). UAE, (May 28, 2000).

Al-Fayoumi. (2003). Retrieved from www.menafn.com/qn_localdeta:L.asp?news_id_14314

Al-Hennawi, Mohammed Saleh. (2007). Analysis and assessment of stocks and bonds. Egypt: Addar Aljami'ah for Publication.

Al-Khatib, Fawaz \& Al-Shara, Monzer. (1994). Amman Stock Exchange and its responsiveness to economic changes. Yarmouk Research Journal, 10(3), 371-390.

Al-Shahat, Nazir. (2000). Stock exchanges. Mansoura-Egypt: University Library, 98101.

Amenc, Noël, Goltz, Felix, Martellini, Lionel \& Ye, Shuyang. (2010). Improved Beta? A Comparison of Index-Weighting Schemes. EDHEC-Risk Institute Publication. Retrieved from http://www.edhec-risk.com/edhec_publications/all_publications/RISKReview.2010-09-22.3904/attachment s/EDHEC-Risk_Publication_Comparison_Index-Weighting_Schemes.pdf 
Amman Stock Exchange Daily Report. (2005). Retrieved May 31, 2005 from www.ase.com.jo

Amman Stock Exchange. (2003). Retrieved from www.ase.com.jo

Badri, Sabah \& Khoury, Rettab. (1971). The study of movements of stock prices in Amman Stock Exchange using the standard models. Studies of Management Science, 24(1), pp. 81-101.

Business-finance.org. (2011). The Determination of China Stock Index Futures Hedging Ratio. Retrieved March 14 , 2012 from http://www.business-finance.org/investment-securities/the-determination-of-china-stock-index-futures-hedg ing-ratio.html

Edwin J. Elto, Martin J. Gruber \& Jeffrey A. Busse. (2004). Are Investors Rational? Choices Among Index Funds. The Journal of Finance, lx(1).

Gitman \& Joehnk. (2002). Fundamentals of Investing (8th ed.). Addison Wesley.

Goetzmann, William N. (1999). Daily Momentum And Contrarian Behavior Of Index Fund Investor. Massimo Massa: Yale School of Management.

Goltz, Felix \& Sahoo, Dev. (2011). What Drives the Performance of Efficient Indices? The Role of Diversification Effects, Sector Allocations, Market Conditions, and Factor Tilts. An EDHEC-Risk Indices \& Benchmarks Publication. Retrieved March 14, 2012 from http://www.edhec-risk.com/indexes/documents/attachments/ERIB_Publication_What_Drives_Performance _of_Efficient_Indices_F.pdf

Le Sourd, Véronique. (2011). Performance of Socially Responsible Investment Funds against an Efficient SRI Index: The Impact of Benchmark Choice when Evaluating Active Managers. EDHEC-Risk Institute Publication. $\quad$ Retrieved March $\quad 14, \quad 2012$ from http://www.edhec-risk.com/edhec_publications/all_publications/RISKReview.2011-09-23.3640/attachment s/EDHEC_Publication_Performance_of_SRI_Index_F.pdf

Madura, Jeff. (2003). Financial Markets and Institutions. (6th ed.). Thomson.

Murat Can Adabag \& José Renato Haas Ornelas. (2004). Behavior and effects of foreign investors in Istanbul $\begin{array}{lllll}\text { stock } & \text { exchange. } & \text { Retrieved } & \text { March } & \text { 14, }\end{array}$ http://papers.ssrn.com/sol3/papers.cfm?abstract_id=656442

Reilly \& Blown. (2000). Investment Analysis and Portfolio Management. (6th ed.). South-Western.

Rules of Procedure of Amman Stock Exchange No. 23. (1997).

Salameh, Mohammad Rashid. (1997). The relationship between the change of the general level of prices and stock prices change in Jordan. Al-Balqa Journal, V(I), 39-50.

Saunders, Cornett. (2004). Financial Markets and Institutions(2nd ed.). McGraw-Hill.

Securities Law No. 23. (1997).

www.arb-api.org/course9/c9_4.htm

www.ase.com.jo

www.menafn.com/9n-localdeta:L.asp?news_id_14314

Yao, Shujie, Luo, Dan and Morgan, Stephen. (2009). Shanghai Stock Exchange Composite Index and Bank Stock Prices in China: A Causality Analysis. Discussion Papers. 
Appendix (1)

\begin{tabular}{|c|c|}
\hline Company & Specialization \\
\hline $3 \mathrm{M}$ & Miscellaneous Industries \\
\hline ALCOA & Aluminum \\
\hline AMERICAN EXPRESS & Financial Services \\
\hline AMERICAN INTEL GROUP & Insurance \\
\hline AT\&T & Communications \\
\hline BANK OF AMERICA & Retail Bank \\
\hline BOEING & Aircraft Industry \\
\hline CATERPILLAR & Trucks \\
\hline CHEVRON & Oil and Gas \\
\hline CITIGROUP & Banks \\
\hline COCO COLA & Soft Drinks \\
\hline DUPONT & Chemicals \\
\hline EXXON MOBIL & Oil and Gas \\
\hline GENERAL ELECTRIC & Electronics \\
\hline SISCO SYSTEMS & Network Systems \\
\hline HEWLETT PACKARD & Computers Devices \\
\hline HOME DEPOT & Cosmetics \\
\hline INTEL & Banks \\
\hline IBM & Fast Food Restaurants \\
\hline JOHNSON\&JOHNSON & Medicines \\
\hline JP MORGAN CHASE & Software \\
\hline MCDONALD'S & Medicines \\
\hline MERCK & Various Industries \\
\hline MICROSOFT & Heating and Cooling Equipment \\
\hline PFIZER & Communications \\
\hline PROCTER\& GAMBLE & Retail Dealer \\
\hline United Technologies Corporation & Media \& Entertainment \\
\hline Verizon Communications & Computers Devices \\
\hline WALMART & Development of Houses \\
\hline WALT DISNEY & Computer Chips \\
\hline
\end{tabular}


Appendix (2)

\begin{tabular}{|c|c|c|}
\hline Company Name & Letter code & B \\
\hline Arab Bank & ARBK & 0.0539 \\
\hline Jordan Islamic Bank & JOIB & 0.2907 \\
\hline Jordan Kuwait Bank & JOKB & 0.2675 \\
\hline The Housing Bank for Trade and Finance & THBK & 0.1010 \\
\hline Arab Jordan Investment Bank & AJIB & 0.4096 \\
\hline Union Bank & UBSI & 0.1792 \\
\hline Arab Banking Corporation / Jordan & $\mathrm{ABCO}$ & 0.1283 \\
\hline Investment bank & JIFB & 0.4821 \\
\hline Capital Bank of Jordan & EXFB & 0.5490 \\
\hline Cairo Amman Bank & CABK & 0.3780 \\
\hline Bank of Jordan & BOJX & 0.5195 \\
\hline Jordan Ahli Bank & JONB & 0.5670 \\
\hline Jordan International Insurance & JIJC & 0.5132 \\
\hline Arab German Insurance & AGICC & 0.4220 \\
\hline Islamic insurance & TIIC & 0.3455 \\
\hline Mediterranean and Gulf Insurance Company - Jordan & MDGF & 0.2000 \\
\hline First Takaful Insurance & FINS & 0.2720 \\
\hline DARCOM for Investment & DRKM & 0.5172 \\
\hline National Portfolio Securities & NPSC & 0.5626 \\
\hline Jordanian Expatriates Investment Holding & JEIH & 0.5695 \\
\hline Jordan Investment Trust & JOIT & 0.2630 \\
\hline Al-Ittihad for Financial Investment & UINV & 0.2630 \\
\hline Arab Financial Investment & AFIN & 0.4241 \\
\hline United Arab Investors & UAIC & 0.5840 \\
\hline Arab East Financial Investment & AEIV & 0.5480 \\
\hline Falcon for Investment and Financial Services & FIFS & 0.4882 \\
\hline Al Amin for Investment & AAFI & 0.4641 \\
\hline United Financial Investments & UCFI & 0.3916 \\
\hline International Brokerage and Financial Markets & IBFM & 0.7370 \\
\hline Investment House for Financial Services & $\mathrm{INVH}$ & 0.4200 \\
\hline Amwal Invest & AMWL & 0.5470 \\
\hline Alamal Financial Investment & AMAL & 0.7890 \\
\hline Al Sanabel International for Islamic Investments Holding & SANA & 0.3315 \\
\hline First for Finance & FIFI & 0.4418 \\
\hline International Cards Company & CARD & 0.3800 \\
\hline First Jordan Investment & FRST & 0.4309 \\
\hline Dimensions of Jordan and the UAE For Commercial Investment & JEDI & 0.2200 \\
\hline Darat Jordan Holdings & DARA & 0.6500 \\
\hline United Group Holdings & UGHI & 0.3660 \\
\hline
\end{tabular}




\begin{tabular}{|c|c|c|}
\hline Alisraa Investment and Islamic Finance & ISRA & 0.4110 \\
\hline Jordan Dubai Properties & REIN & 0.2475 \\
\hline Resources Company for Development and Investment & JOMA & 0.1280 \\
\hline Al Ittihad Land Development & ULDC & 0.4020 \\
\hline Al Tajamouat Catering and Housing & JNTH & 0.9340 \\
\hline Specialized Investment Compounds & SPIC & 0.5550 \\
\hline Real estate development & REDV & 0.2600 \\
\hline Arab Real Estate Development & ARED & 0.5730 \\
\hline Real Estate and Investment Portfolio & PETT & 0.4123 \\
\hline The Investors and Eastern Arab for Industrial and Real Estate Investments & IEAI & 0.2550 \\
\hline Arab East for Real Estate Investments & REAL & 0.2810 \\
\hline Jordanian Real Estate Company for Development & JRCD & 0.6857 \\
\hline Amad Investment and Real Estate Development & AMAD & 0.5360 \\
\hline Emaar Investments \& Real Estate Development & EMAR & 0.6275 \\
\hline Taameer Jordan Holdings & TAMR & 0.4746 \\
\hline Charter Real Estate Investment & MEET & 0.5815 \\
\hline Al Kafaa for Real Estate Investments & HIPR & 0.6185 \\
\hline Professional for Real Estate Investment and Housing & PROF & 0.6483 \\
\hline Ammon International Inc. Diversified Investment & AMON & 0.7050 \\
\hline AD-Dulayl Industrial Park \& Real Estate & IDMC & 0.8243 \\
\hline Al Bilad Medical Services & ABMS & 0.4530 \\
\hline Arab International Company for Education and Investment & AIEI & 0.4920 \\
\hline al ettehad school & ITSC & 0.3731 \\
\hline Al Tajamouat for Tourism Projects & MERM & 0.2454 \\
\hline Al-Dawliyah For Hotels \& Malls & MALL & 0.2331 \\
\hline Salam International Transport and Trading & SITT & 0.3896 \\
\hline Transport \& Investment Barter Company & NAQL & 0.5690 \\
\hline Alia - The Royal Jordanian Airlines & RJAL & 0.4200 \\
\hline Distances for the specialized transport & MSFT & 0.4510 \\
\hline Al Mutakamelah Transport Company & ABUS & 0.3800 \\
\hline Jordan Telecom & JTEL & 0.0694 \\
\hline Al Faris National Company for Investment and Export & CEBC & 0.6477 \\
\hline Jordan Press Foundation / Al Rai & PRES & 0.3446 \\
\hline Jordan Press \& Publishing / Adastour & JOPP & 0.3350 \\
\hline Jordan Electric Power & JOEP & 0.7969 \\
\hline Jordan Petroleum Refinery- Jobtrul & JOPT & 0.7342 \\
\hline Al Ahlia Enterprises & ABLA & 0.1962 \\
\hline Specialized Jordanian Investment & SIJC & 0.2132 \\
\hline Bin Dar for Trade and Investment & BIND & 0.0757 \\
\hline Darwish Khalili \& Sons & DKHS & 0.7000 \\
\hline Oftec Group for Holding & BDIN & 0.3040 \\
\hline South Electronics & SECO & 0.8530 \\
\hline
\end{tabular}




\begin{tabular}{|l|c|c|}
\hline Afaq for Energy & MANE & 0.0300 \\
\hline Dar Al Dawa Development and Investment & DADI & 0.7498 \\
\hline Middle East Pharmaceutical and Chemical Industries and Medical Appliances & MPHA & 0.1475 \\
\hline Jordanian Pharmaceutical Manufacturing & JPHM & 0.2801 \\
\hline Industrial Commercial \& Agricultural / Production & ICAG & 0.4500 \\
\hline National Chlorine Industries & NATC & 0.5150 \\
\hline Arab Pesticides and Veterinary Drugs & MBED & 0.7380 \\
\hline Al Ekbal for investment & ITCC & 0.4306 \\
\hline Aletehad Factory for the production of tobacco and cigarettes & UTOB & 0.3799 \\
\hline Jordan Phosphate Mines & JOPH & 0.1153 \\
\hline Jordan Cement Factories & JOCM & 0.1751 \\
\hline Arab Potash & APOT & 0.0736 \\
\hline Jordan Steel & JOST & 0.8620 \\
\hline National Aluminum & NATA & 0.6350 \\
\hline Ready Mix Concrete and Construction Supplies & RMCC & 0.3200 \\
\hline National Cable and Wire Manufacturing & WIRE & 0.5037 \\
\hline Jordan New Cable & JNCC & 0.3728 \\
\hline United Cable Industries & UCIC & 0.5035 \\
\hline Jordan Worsted Mills & JOWM & 0.5490 \\
\hline
\end{tabular}

